\title{
Adaptation of dairy cows to increasing degrees of incomplete milk removal during a single milking interval
}

\author{
A. Albaaj, ${ }^{,}$P. G. Marnet,† C. Hurtaud, ${ }^{*}$ and J. Guinard-Flament ${ }^{* 1}$ \\ *Pegase, Agrocampus Ouest, INRA, 35590, Saint-Gilles, France \\ †Agrocampus Ouest, 35000, Rennes, France
}

\begin{abstract}
Milk accumulation in the udder decreases milk secretion and this effect is explained as well by the effects of the quantity of milk stored in the udder as by the duration and repetition of periods of milk stasis. This experiment aimed to better understand the underlying mechanisms of decreased milk yield in response to the specific effects of the quantity of milk stored in the udder, independent from storage duration, on milk yield and composition. Sixteen Holstein cows were assigned to 4 blocks of 4 cows in a $4 \times 4$ Latin square design using 7-d periods, with a 4-d sampling period and a 3 -d washout period. Cows were milked twice daily at approximately 0700 and $1630 \mathrm{~h}$ throughout the trial. Treatments consisted of 4 degrees of milk removal (100, 70, 40, and 0\%) applied at one morning milking, designated M0. Effects of the quantity accumulated were studied in relation to udder distension, via measurements of the total distance between the ends of the 4 teats, and cisternal capacity, via the evaluation of cisternal area by ultrasonographic scan at 1 and $9 \mathrm{~h}$ after M0. The effect of the quantity accumulated was also evaluated in relation to mammary epithelium permeability by determining plasma lactose concentrations $1 \mathrm{~h}$ before and 4,7 , and $10 \mathrm{~h}$ after M0. Leaving milk in the udder at M0 decreased milk production during the M0-M1 interval in a negative curvilinear manner. As a result, M0+M1 milk yield decreased or tended to decrease significantly by $-1.3,-5.3$, and $-12.8 \mathrm{~kg}$ for the 70,40 , and $0 \%$ treatments compared with the $100 \%$ treatment $(41.7 \pm 1.26 \mathrm{~kg} / \mathrm{d})$, respectively. Negative carry-over effects on milk yield were observed until the M3 milking only for the 40 and $0 \%$ treatments, and no differences were observed between the effects of these treatments. The total distance between teats increased significantly but to decreasing degrees during the M0-M1 interval. For the 40 and 0\% treatments,
\end{abstract}

Received January 15, 2018.

Accepted May 18, 2018.

${ }^{1}$ Corresponding author: jocelyne.flament@agrocampus-ouest.fr cisternal area, which was increased $1 \mathrm{~h}$ after M0 milking, exhibited no further increase during the M0-M1 interval, suggesting cisternal distension was close to maximum. Simultaneously, lactose concentrations increased in blood plasma for only these 2 treatments, and this increase occurred earlier for the $0 \%$ treatment. It was also observed that cows presenting the earliest increases in plasma lactose concentrations during milk accumulation lost more milk in response to extended milking intervals.

Key words: dairy cow, incomplete milking, cisternal capacity and udder distension, blood lactose

\section{INTRODUCTION}

Cows are typically milked early in the morning and late in the afternoon, with intervals ranging from 12:12 to 10:14 (Armstrong, 1997; Brocard et al., 2015). This management avoids periods of milk accumulation that are too long during the night; daily milk yields are reduced by $-2.4,-4.1$, and $-8.4 \%$ with $6.5: 17.5$, $5: 19$, and 4:20 intervals, respectively, when compared with 10:14 to 11:13 milking intervals (Ichikawa and Fujishima, 1982; Rémond et al., 2009; Dutreuil et al., 2016). In dairy cows, increasing milking intervals induces a curvilinear decrease in the rate of milk secretion. The rate of secretion remains relatively constant until $12 \mathrm{~h}$, decreases slightly from 12 to $16-18 \mathrm{~h}$, and then decreases rapidly (Elliott et al., 1960; Wheelock et al., 1966; Stelwagen et al., 2008). Additionally, negative carry-over effects resulting from the lengthening of the milking interval have also been reported for milk yield, with significantly reduced milk secretion during the first following milking interval and a gradual recovery during subsequent milking intervals (Wheelock et al., 1966; Stelwagen et al., 2008). The delay in the recovery of milk secretion depends on the duration of the extended milking interval. Longer extended milking intervals require more numerous subsequent milkings to restore the previous milk yield.

Lengthening a milking interval entails the storage of a larger quantity of milk in the udder for a longer 
period of time. Both increased amounts of milk stored and longer periods of milk stasis could have negative effects on milk yield, as previously demonstrated in trials using incomplete milking with different degrees of milk removal based on the expected yield at milking (Dodd and Clough, 1962; Schmidt et al., 1964; Wheelock et al., 1965). These authors all showed that a higher quantity of milk stored in the udder had an increased inhibitory effect on the rate of milk secretion. Nevertheless, in these studies, it is difficult to distinguish the exact effects of milk quantity from those due to the repetition of periods of milk accumulation because incomplete milkings were performed over periods of several days. A better model could be to use variations in milk quantity by using different degrees of milk removal applied during a same single extended milking interval as this was shown to be sufficient to decrease milk secretion rates during extended and subsequent milking intervals (Stelwagen et al., 2008; Charton et al., 2016).

Several studies reviewed by Davis et al. (1999) have shown the role of alveolar compartment drainage, cistern size, and the ability of the udder to distend in the regulation of milk secretion rates in response to extended milking intervals. The alveolar compartment in the bovine udder is more than $90 \%$ full at approximately $16 \mathrm{~h}$ postmilking (Davis et al., 1998). Then, milk continues to drain and accumulate in the cistern until the cistern storage capacity (volume and compliance) limits milk accumulation (Stelwagen et al., 1996). An extended milking interval is also associated with the loss of mammary barrier integrity, as noticed with increased permeability of the mammary epithelium in dairy cows (Stelwagen et al., 1997; Guinard-Flament et al., 2011b). Based on the efflux of lactose from milk into blood plasma, this increase in permeability occurs as the rate of milk secretion begins to decrease (i.e., approximately 17 to $18 \mathrm{~h}$ after milking; Stelwagen et al., 1997; Davis et al., 1998; Stelwagen et al., 2008). Among the different structures connecting adjacent mammary epithelial cells, tight junctions $(\mathbf{T J})$ prevent paracellular transport of ions and small molecules from blood to the milk compartment and vice versa (Stelwagen and Singh, 2014). According to these authors, the maintenance of TJ integrity is necessary to maintain milk synthesis and secretion during lactation, and early changes in TJ integrity in response to milk accumulation could be related to cistern storage capacity. When the cistern is full, newly secreted milk would accumulate in the alveolar compartment and induce the disruption of mammary TJ integrity.

Although cisternal capacity and compliance of the udder and mammary barrier integrity all contribute to the mammary adaptation of dairy cows to an extended milking interval, these criteria have never been studied together to better understand the mechanisms of milk accumulation that downregulate milk yield. Thus, the present study aimed to describe the effects of increasing amounts of milk stored in the udder on milk yield and composition in relation to udder distension, cisternal capacity, and mammary epithelium permeability. These changes were described in relation to various degrees of milk removal during and after a single milk accumulation interval.

\section{MATERIALS AND METHODS}

\section{Cow Management and Experimental Design}

The experiment was performed at the INRA experimental farm of Méjusseaume $\left(48.11^{\circ} \mathrm{N}, 1.71^{\circ} \mathrm{W}\right.$; Brittany, France) using 12 multiparous and 4 primiparous Holstein dairy cows in compliance with the National Legislation on Animal Care (authorization number: B 35-275-23). At the start of the experiment, cows averaged $603 \pm 57 \mathrm{~kg}$ of $\mathrm{BW}$ and $55 \pm 9$ DIM. Cows had symmetrical udders and were free of clinical mastitis.

Cows were randomly assigned to 1 of 4 groups based on parity, DIM, milk yield, milk fat and protein concentrations, SCC, cisternal area just after milking, distance between teat ends (measured $7 \mathrm{~h}$ after milking), and BW. Each group was assigned to one of the 4 treatments according to a Latin square design with 4 periods of $1 \mathrm{wk}$. This period length was chosen to avoid any carry-over effect of treatments on the following period, which is consistent with Wheelock et al. (1965, 1966), who reported that milk yield and composition returned to initial levels within 3 to $4 \mathrm{~d}$ after resumption of twice-daily milking.

Treatments consisted of 4 degrees of milk removal $(100,70,40$, and $0 \%)$ applied at one milking, designated Mo. The degree of milk removal and the subsequent effects on milk yield and composition were analyzed at the following M1 milking (milk accumulation effect) and subsequent milking until M7 (carry-over effects). Cows were milked twice daily throughout the experiment, using 9.5:14.5 intervals, at approximately 0700 and $1630 \mathrm{~h}$. The M0 milking was an AM milking. Cows at the M0 milking were milked normally (milk removal of $100 \%$ ), were not milked (milk removal of $0 \%$; cows stayed in the stable), or were incompletely milked (milk removal of 70 or $40 \%$ ). For the 2 last treatments, the average milk yield of the 4 preceding morning milkings was used to determine the expected milk yield at the M0 milking. Cows were milked until the quantity matching 70 or $40 \%$ of the expected milk was obtained according to the in-line milk meter of the milking system (Rotary 
milking parlor, milk meter MM25, DeLaval France, Elancourt, France).

Cows were kept indoors in loose-box housing and were fed twice-daily at 0830 and $1630 \mathrm{~h}$. They were offered the same diet throughout the experiment to avoid any feeding effect on milk yield. The diet was calculated to meet the requirements of twice-daily milked cows (INRA, 2007) and consisted, on a DM basis, of $64.7 \%$ corn silage, $15 \%$ energy concentrate (containing $20 \%$ barley, $20 \%$ wheat, $20 \%$ corn, $20 \%$ beet pulp, $15 \%$ wheat bran, $3 \%$ molasses, $1 \%$ soybean oil, and $1 \%$ sodium chloride), $8 \%$ formaldehyde-treated soybean meal, $10 \%$ dehydrated alfalfa, $0.8 \%$ urea, and $1.5 \%$ minerals and vitamins.

\section{Sampling and Analyses}

Milk. Milk yield and the exact time of milking were recorded at each milking. The milk yield was expressed in kilogram either per milking interval or for 2 successive milking intervals (daily production). Milk composition was measured at each milking, except on $\mathrm{d}$ 6 and 7 of the experimental week. Milk fat, protein, and lactose concentrations were determined by infrared analysis (MilkoScan, Foss Electric, Hillerød, Denmark). Somatic cell counts were measured using an automatic cell counter (Fossmatic 5000, Foss Electric), and values were transformed to SCS using a base-2 log-transformation to standardize data distributions [SCS $=\log _{2}$ $(\mathrm{SCC} / 100,000)+3]$.

Udder Morphology. Udder distension and cisternal capacity were assessed by measuring the total distance between the 4 teat ends and measuring cisternal size. The distance between teats increases linearly with time elapsed postmilking (at $0,6,8$, and $12 \mathrm{~h}$ after milking, Miller et al., 1995). When milk accumulates, the elastic median suspensory ligament stretches, permitting the floor of the udder to sag and causing the teats to point outward from the sides of the udder (Swett et al., 1942) rather to keep their vertical positions. This is why we decided to evaluate udder distension by measuring total distance between the 4 teat ends as a way to easily evaluate and to amplify the magnitude of udder expansion as done previously by Sabuncuoglu and Coban (2007). Over the 15 previous days before the start of the experiment, cows were trained to both measurements to prevent unsolicited activation of the milk ejection reflex (13 measurements). One and nine hours after the M0 milking, the total distance between the 4 teat ends was measured using a Vernier caliper, whereas cisternal size was assessed indirectly by measuring cisternal area by ultrasonographic scan, a noninvasive method of visualizing the internal structure of the mammary gland (Bruckmaier et al., 1994; Ayadi et al., 2003). For each measurement of the cisternal area, 4 scans of the right rear quarter were performed using a 2-D ultrasonograph (Mini Focus 1402, BK Medical, Herlev, Denmark) equipped with a $3.5-\mathrm{MHz}$ convex probe (type 8803, BK Medical). This probe allowed penetration of up to $14 \mathrm{~cm}$ into mammary tissues. Contact gel (Zero-gel, ECG-EEG, Asept InMed, Quint Fonsegrives, France) was applied to the skin of the udder to exclude air between the probe and the udder. Scans were performed in the stalls with cows standing, and care was taken to use the same position for each cow and probe between measurements at each sampling period, with the probe close to and parallel to the teat and pointing directly toward the udder cistern. Images were transmitted to a computer and analyzed using image analysis software (ImageJ, National Institutes of Health, USA; http://rsb.info.nih.gov/ij/). Because images were sometimes not representative on the first scan, the surface area average was calculated using the 3 last scans of each measurement.

Mammary Epithelium Permeability. Plasma lactose concentrations and $\mathrm{Na}$ and $\mathrm{K}$ concentrations in milk were measured to evaluate TJ integrity. The Na and $\mathrm{K}$ concentrations in milk collected at the M1 milking were determined by atomic absorption spectrophotometry (Spectra AA220, Varian, Les Ulis, France) as reported previously (Murthy and Rhea, 1967). Analysis was done in duplicate (CV <3\%). Lactose concentrations in blood plasma were determined $1 \mathrm{~h}$ before and 4, 7, and $10 \mathrm{~h}$ after M0 milking from blood samples (7-8 $\mathrm{mL}$ ) collected from the coccygeal vein using heparinized vacutainers (VT-050SHL, Venoject, Terumo Europe, Leuven, Belgium). Plasma was obtained after centrifugation $\left(10 \mathrm{~min}\right.$ at $2,500 \times g$ and $\left.4^{\circ} \mathrm{C}\right)$ and stored at $-20^{\circ} \mathrm{C}$. The concentration of lactose in blood plasma was measured in duplicate $(\mathrm{CV}<3 \%)$ using a colorimetric enzymatic reaction (kit for lactose/D-galactose, Roche, Meylan, France) on a multiparameter analyzer (Kone Instruments Corporation, Espoo, Finland).

\section{Statistical Analysis}

Due to the application of the wrong degree of milk removal, one cow was removed from the study at period 3. Statistical analysis was performed using SAS software (version 7.3, SAS Institute Inc., Cary, NC). The milk $\mathrm{Na}$ and $\mathrm{K}$ data were analyzed using ANOVA with the MIXED procedure, including animals as the random effect and period and treatment as fixed effects. Other data were analyzed using ANOVA within the MIXED procedure, considering milking or sampling time as repeated measures. The model included the 
Table 1. Milk yield and milk fat, protein, and lactose yields in response to decreasing levels of milk removal at M0 milkings in dairy cows ${ }^{1}$

\begin{tabular}{|c|c|c|c|c|c|c|c|c|c|}
\hline \multirow[b]{2}{*}{ Item } & \multirow[b]{2}{*}{$\begin{array}{l}\text { Milking } \\
\text { order }\end{array}$} & \multicolumn{4}{|c|}{ Level of milk removal (\%) } & \multirow[b]{2}{*}{$\begin{array}{l}\text { Pooled } \\
\text { SEM }\end{array}$} & \multicolumn{3}{|c|}{$P$-value } \\
\hline & & 100 & 70 & 40 & 0 & & $\begin{array}{l}\text { Milk } \\
\text { removal }\end{array}$ & Milking & $\begin{array}{l}\text { Milk removal } \\
\times \text { milking }\end{array}$ \\
\hline & M2 & $21.9^{\mathrm{ab}}$ & $22.0^{\mathrm{a}}$ & $20.8^{\mathrm{b}}$ & $20.4^{\mathrm{b}}$ & & & & \\
\hline & M3 & $15.2^{\mathrm{a}}$ & $14.7^{\mathrm{ab}}$ & $14.2^{\mathrm{ab}}$ & $13.9^{\mathrm{b}}$ & & & & \\
\hline & M4 & 23.7 & 24.2 & 23.8 & 23.5 & & & & \\
\hline & M7 & 16.0 & 16.1 & 16.5 & 16.3 & & & & \\
\hline \multirow{6}{*}{ Fat yield $(\mathrm{g})$} & M1 & $768^{\mathrm{d}}$ & $997^{\mathrm{c}}$ & $1,117^{\mathrm{b}}$ & $1,470^{\mathrm{a}}$ & 54.2 & $<0.0001$ & $<0.0001$ & $<0.0001$ \\
\hline & M2 & $809^{\mathrm{b}}$ & $837^{\mathrm{ab}}$ & $901^{\mathrm{ab}}$ & $912^{\mathrm{a}}$ & & & & \\
\hline & M3 & 531 & 510 & 502 & 503 & & & & \\
\hline & M4 & 818 & 795 & 812 & 777 & & & & \\
\hline & M5 & 673 & 698 & 683 & 660 & & & & \\
\hline & M6 & 803 & 790 & 786 & 796 & & & & \\
\hline & M5 & 475 & 472 & 457 & 447 & & & & \\
\hline & M6 & 694 & 699 & 683 & 686 & & & & \\
\hline & M7 & 454 & 456 & 461 & 458 & & & & \\
\hline \multirow[t]{7}{*}{ Lactose yield (g) } & M1 & $899^{\mathrm{c}}$ & $1,109^{\mathrm{b}}$ & $1,256^{\mathrm{a}}$ & $1,282^{\mathrm{a}}$ & 34.3 & 0.0054 & $<0.0001$ & $<0.0001$ \\
\hline & M2 & $1,044^{\mathrm{a}}$ & $1,050^{\mathrm{a}}$ & $990^{\mathrm{b}}$ & $957^{\mathrm{b}}$ & & & & \\
\hline & M3 & $729^{\mathrm{a}}$ & $703^{\mathrm{ab}}$ & $674^{\mathrm{b}}$ & $659^{\mathrm{b}}$ & & & & \\
\hline & M4 & 1,127 & 1,155 & 1,130 & 1,113 & & & & \\
\hline & M5 & 800 & 802 & 779 & 766 & & & & \\
\hline & M6 & 1,145 & 1,150 & 1,130 & 1,134 & & & & \\
\hline & M7 & 767 & 775 & 787 & 780 & & & & \\
\hline
\end{tabular}

\footnotetext{
${ }^{\mathrm{a}-\mathrm{d}}$ Least squares means within a row with different superscripts differ at $P<0.05$.
}

${ }^{1} \mathrm{M} 0$ to $\mathrm{M} 7$ = one morning milking designated as M0 and subsequent milkings.

effects of animal as random effects and period, treatment, milking (or sampling) time, and the treatment $\times$ milking (or sampling) time interaction as fixed effects. Differences between least squares means were determined using Student's $t$-tests. The results are expressed as least squares means \pm standard errors of the mean. The significance threshold was set at $P \leq 0.05$ and the threshold for a tendency at $P \leq 0.10$.

\section{RESULTS}

The average milking interval duration over the study was $562 \pm 9$ min during the day and $870 \pm 12 \mathrm{~min}$ at night. The daytime M0-M1 interval was lengthened due to the measurements performed on animals (649 $\pm 3 \mathrm{~min}$ ). Consequently, the following night interval between M1 and M2 was shortened (829 \pm 5 min). At the M0 milking, the quantity of milk removed from the udder averaged 23.0, 16.9, 9.7, and $0 \mathrm{~kg}$ for the 100, 70,40 , and $0 \%$ treatments, respectively. The quantity of milk left in the udder at M0 was $6.1 \pm 2.39,13.3 \pm$ 2.05 , and $23.0 \pm 3.18 \mathrm{~kg}$ for the 70,40 , and $0 \%$ treatments, respectively.

\section{Milk Yield at M1 and Subsequent Milkings}

Due to incomplete or no milking at M0, the amount of milk collected at M1 increased by $+4.5,+8$, and $+10.2 \mathrm{~kg}$ for milk removal of 70,40 , and $0 \%$, respectively, compared with removal at $100 \%(P<0.001$; Table $1)$. Values for all treatments differed significantly. For the daily production $(\mathrm{M} 0+\mathrm{M} 1)$, the quantity of milk removed was $41.7 \pm 1.26 \mathrm{~kg}$ for the $100 \%$ treatment, and this decreased or tended to decrease by $-1.3 \mathrm{~kg}(P$ $=0.077),-5.3 \mathrm{~kg}(P<0.0001)$, and $-12.8 \mathrm{~kg}(P<$ 0.0001 ) for the 70,40 , and $0 \%$ treatments, respectively, compared with the $100 \%$ treatment [standard error of the differences of means $($ SED $)=0.73]$.

Negative carry-over effects on milk yield were observed only at the M2 and M3 milkings and for treatments 40 and $0 \%$ (Table 1). Compared with the $100 \%$ treatment, cows showed or tended to show a change in production of $-1.0 \mathrm{~kg}(P<0.08)$ and $-1.5 \mathrm{~kg}(P<$ $0.05)$ at the M2 milking (i.e., -5 and $-6.8 \%)$ and -1.0 $\mathrm{kg}(P<0.09)$ and $-1.3 \mathrm{~kg}(P<0.03)$ at the M3 milking (i.e., -6.6 and $-8.6 \%$; SED $=0.58 \mathrm{~kg}$ ) for the 40 and $0 \%$ treatments, respectively. The daily milk yield 
Table 2. Milk composition in response to decreasing levels of milk removal at M0 milkings in dairy cows ${ }^{1}$

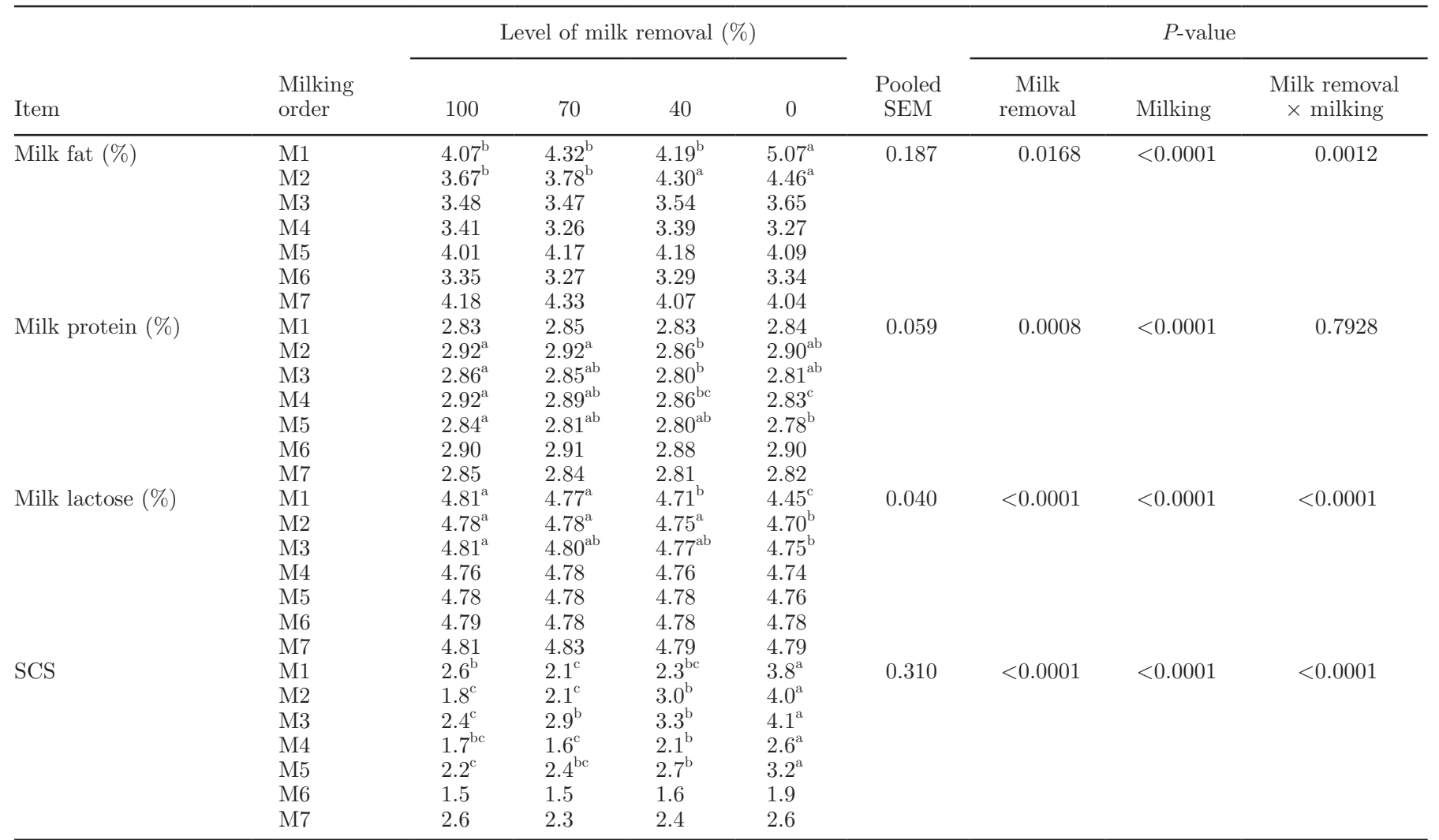

${ }^{\mathrm{a}-\mathrm{c}}$ Least squares means within a row with different superscripts differ at $P<0.05$.

${ }^{1} \mathrm{M} 0$ to $\mathrm{M} 7=$ one morning milking designated as M0 and subsequent milkings.

on the subsequent day (M2+M3 milking) was decreased by $-2.0 \mathrm{~kg}(P<0.005)$ and $-2.7 \mathrm{~kg}(P<0.001)$ for the 40 and $0 \%$ treatments, respectively, compared with the $100 \%$ treatment $(37.0 \mathrm{~kg} / \mathrm{d} ; \mathrm{SED}=0.73)$.

\section{Milk Composition at M1 and Subsequent Milkings}

Milk fat, protein, and lactose yields varied between treatments at M1, and carry-over effects were observed on subsequent milkings only for M2 and M3 milkings (Table 1). At the M1 milking, milk fat and protein yields increased as the degree of milk removal decreased $(P<0.0001$ and 0.02 , respectively). Milk lactose yields for the 40 and $0 \%$ treatments increased by $+358 \mathrm{~g}$ $(P<0.0001)$ and $+383 \mathrm{~g}(P<0.0001)$, respectively, compared with the $100 \%$ treatment $(\mathrm{SED}=27.0)$. Decreased lactose and protein yields were observed at M2 and M3 for the 40 and 0\% treatments compared with the $100 \%$ treatment $(P<0.05$ and 0.002 at $\mathrm{M} 2$ and $P$ $<0.05$ and 0.05 at M3, respectively), with no difference between the 0 and $40 \%$ treatments. In contrast, milk fat yield tended to be $(P<0.075)$ or was increased ( $P$ $<0.0001)$ at the M2 milking for the 40 and $0 \%$ treatments, respectively, compared with the $100 \%$ treatment
$(\mathrm{SED}=0.52)$. At the M3 milking, no difference was observed in milk fat yield between treatments.

The milk fat concentration and SCS increased at the M1 milking only for the $0 \%$ treatment $(+1.00$ percentage point and +1.2 units, respectively) and increased at the M2 milking for the 40 and $0 \%$ treatments (milk fat concentration: +0.63 and +0.79 percentage point, $P$ $<0.02$; SCS: +1.2 and +2.2 units, $P<0.0001$, respectively; Table 2). There was no further effect on milk fat concentration after M2, but SCS remained elevated until M5 for both treatments, with treatment $0 \%$ showing the highest score.

Milk protein concentration did not change at the M1 milking in response to treatments (Table 2). However, carry-over effects were detected from M2 until the M5 milking $(P<0.001)$, with values slightly lower for either the 40 or $0 \%$ treatments, or both, compared with the $100 \%$ treatment. The maximal decrease was achieved at the M4 milking ( -0.04 and -0.09 percentage points, respectively).

Milk lactose concentrations decreased at the M1 milking for the 40 and $0 \%$ treatments compared with the $100 \%$ treatment, with the lowest value for the $0 \%$ treatment $(P<0.0001 ;$ Table 2$)$. Decreased lactose 


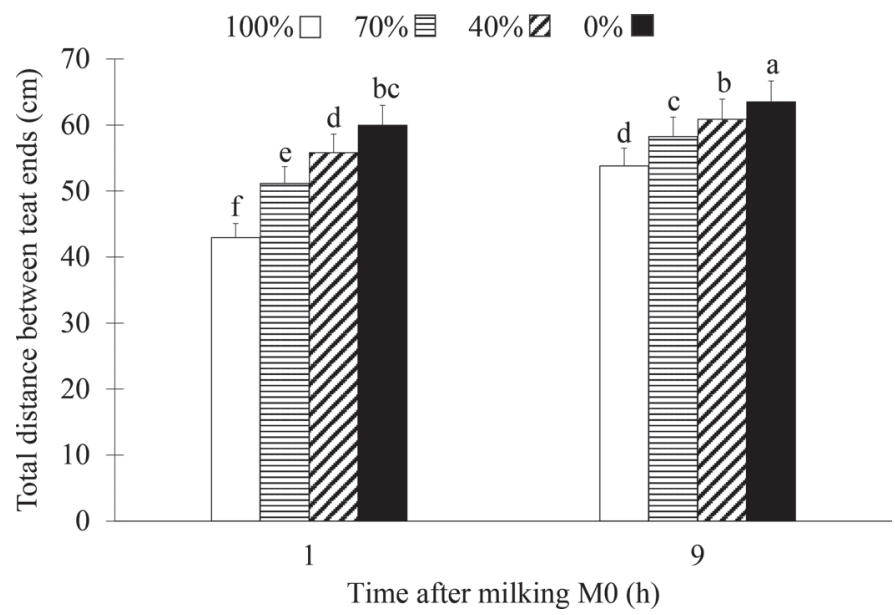

Figure 1. Total distance between the 4 teat ends of the udder 1 and $9 \mathrm{~h}$ after decreasing levels of milk removal at M0 milkings in dairy cows (levels of milk removal: $100,70,40$, and $0 \%$ ). $\mathrm{M} 0=$ one morning milking. Values with different letters $(\mathrm{a}-\mathrm{f})$ differ at $P<0.05$. Vertical bars represent SEM.

concentrations were also observed at the M2 and M3 milkings but only for the $0 \%$ treatment $(-0.08$ and -0.06 percentage point, $P<0.01$ and $<0.03$, respectively; SED $=0.281$ ).

\section{Udder Morphology}

The total distance between the 4 teats ends differed between treatments after the M0 milking, increasing as the degree of milk removal decreased $(42.9,51.1$, 55.8 , and $60.0 \mathrm{~cm}$ for the $100,70,40$, and $0 \%$ treatments, respectively, SEM $=2.59$, Figure 1$)$. The total distance increased between the M0 and M1 milkings for all treatments, but this increase was smaller as the degree of milk removal decreased: $+10.9 \mathrm{~cm}(P<0.0001)$, $+7.1 \mathrm{~cm}(P<0.0001),+5.1 \mathrm{~cm}(P<0.0001)$, and $+3.5 \mathrm{~cm}(P<0.005)$ for the $100,70,40$, and $0 \%$ treatments, respectively $(\mathrm{SED}=1.08)$. Just before the M1 milking, the $0 \%$ treatment group exhibited the greatest distance $(63.5 \mathrm{~cm}$ vs. $53.8,58.3,60.9 \mathrm{~cm}$ for the 100 , 70 , and $40 \%$ treatments, respectively; $\mathrm{SEM}=2.59 ; P$ $<0.0001)$.

Cisternal area after M0 milkings averaged $13.5 \pm 3.11$ $\mathrm{cm}^{2}$ for the $100 \%$ treatment and increased by +25.3 $\mathrm{cm}^{2}(P<0.0001),+31.2 \mathrm{~cm}^{2}(P<0.0001)$, and +31.3 $\mathrm{cm}^{2}(P<0.0001)$ for the 70,40 , and $0 \%$ treatments, respectively, compared with the $100 \%$ treatment (SED $=2.78$; Figure 2). Just before M1 milkings, cisternal areas were always greater for the 70,40 , and $0 \%$ treatments than for the $100 \%$ treatment, as shown in Figure 3. However, between the M0 and M1 milkings, cisternal area did not increase significantly for the 40 and $0 \%$ treatments (Figure 4). Cisternal area averaged 48.1 and $48.8 \mathrm{~cm}^{2}$ before the M1 milking in these 2 treatments, respectively $(\mathrm{SEM}=3.16)$. Between the $\mathrm{M} 0$ and $\mathrm{M} 1$ milkings, cisternal area only increased for the 70 and $100 \%$ treatments (by $+24.0 \mathrm{~cm}^{2}$ and $+8.4 \mathrm{~cm}^{2}$; SED $=$ 2.73 and $2.82 ; P<0.0001$ and $<0.004$, respectively).

\section{Mammary Epithelium Permeability}

For the 100 and $70 \%$ treatments, plasma lactose concentrations did not vary between the M0 and M1 milkings (Figure 5). Lactose concentrations increased significantly in the $40 \%$ treatment group only at 10 $\mathrm{h}$ after M0 milkings $(+39.6 \mathrm{mg} / \mathrm{L}, \mathrm{SED}=14.36 ; P$ $=0.0067)$. In the $0 \%$ treatment group, plasma lactose concentrations increased earlier; at $4 \mathrm{~h}$ after the M0 milking, the concentration increased by $+36.1 \mathrm{mg} / \mathrm{L}$ (SED $=14.36, P=0.0131)$, and it increased to 178.7 $\mathrm{mg} / \mathrm{L} 10 \mathrm{~h}$ after the M0 milking $(\mathrm{SED}=14.36 ; P<$ $0.0001)$.

At M1 milkings, $\mathrm{K}$ concentrations in milk decreased only in the $0 \%$ treatment group compared with the $100 \%$ treatment $(P<0.001$; Table 3$)$. The Na concentrations in milk increased for the $40 \%$ treatment group, and increased the most in the $0 \%$ treatment group $(P<0.0001)$. As a result, $\mathrm{Na} / \mathrm{K}$ ratios in milk measured at M1 milkings increased steadily for the 40 and $0 \%$ treatments $(+0.07$ and +0.17 units compared with the $100 \%$ treatment, $P<0.05$ and $P<0.0001$, respectively; SED $=0.033$ ), and ratios did not vary in the $70 \%$ treatment group.

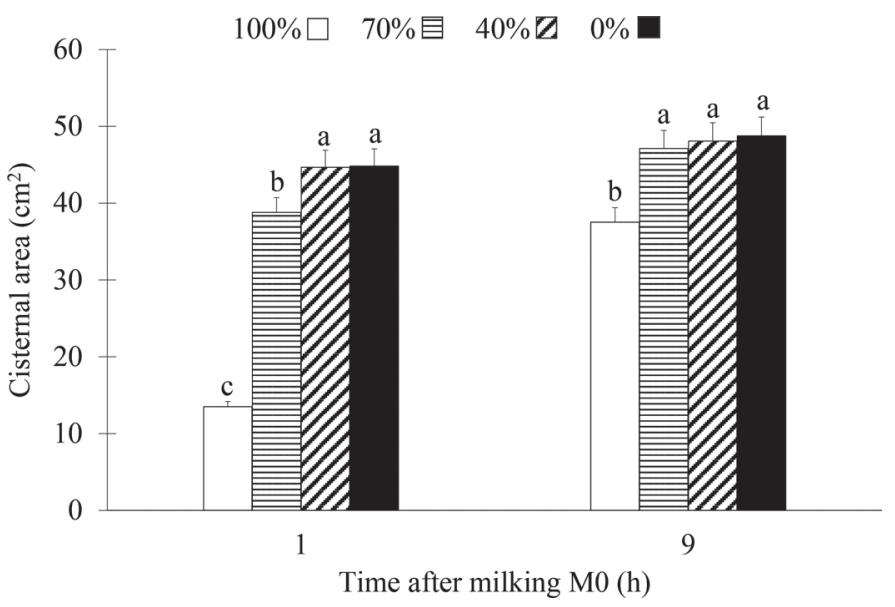

Figure 2. Cisternal surface area of right rear quarter 1 and $9 \mathrm{~h}$ after decreasing levels of milk removal at M0 milkings in dairy cows (levels of milk removal: $100,70,40$, and $0 \%$ ). M0 = one morning milking. Values with different letters $(\mathrm{a}-\mathrm{c})$ differ at $P<0.05$. Vertical bars represent SEM. 


\section{DISCUSSION}

The present experiment aimed to describe the effects of 4 degrees of milk removal $(100,70,40$, and $0 \%)$ at a single milking, designated M0, to determine how dairy cows adapt to the quantity of milk stored in the udder during milk accumulation interval and subsequent milking intervals, regardless of the duration of milk stasis.

\section{Milk Yield at M1 and Subsequent Milkings}

In the present study, leaving milk in the udder at M0 decreased milk secretion during the following milking interval (M0-M1 interval). This downregulation was proportional to the quantity of milk left and showed a negative curvilinear relationship. Similar curvilinear responses were previously described when lengthening milking intervals (i.e., when increasing both milk quantity and storage duration in the udder; Elliott et al., 1960; Wheelock et al., 1966; Stelwagen et al., 2008). This further confirms the major role of milk stasis on milk synthesis and secretion as already reviewed in Davis et al. (1999).

(a)

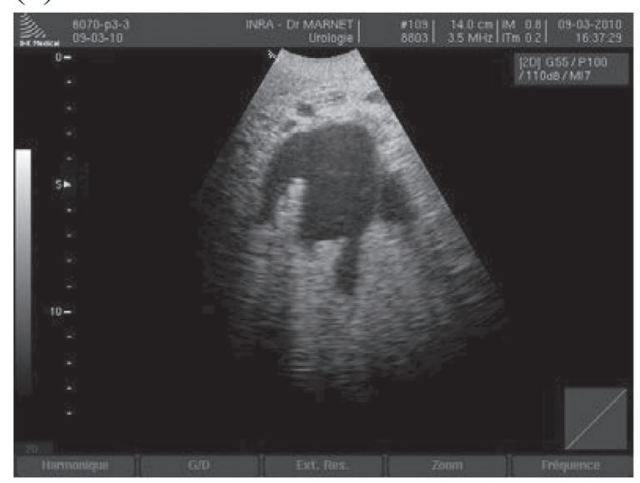

(c)

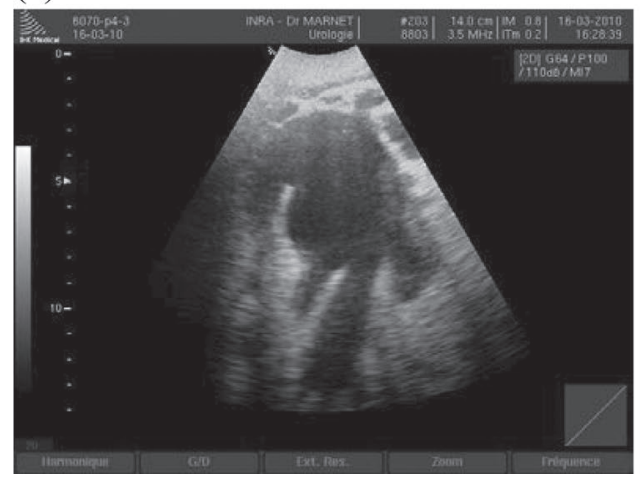

In the present study, milk secretion was slightly reduced by leaving $30 \%$ of the milk in the udder (treatment 70\%): $1.6 \mathrm{~kg}$ less milk was produced between M0 and M1 milkings. Ultrasonography performed just after the M0 milking showed increased cisternal area for this treatment, meaning that milk left in the udder at M0 was at least partially present in the cistern. This could explain why cows exhibited small reductions in milk yield in response to such incomplete milking. If this $30 \%$ of milk left unremoved was stored exclusively in the alveolar compartment, the negative effect on milk secretion would have been increased. For example, Negrao and Marnet (2006) reported a $4 \mathrm{~kg} / \mathrm{d}$ reduction in milk yield in Holstein cows with $12 \%$ residual milk compared with yield in cows with $7.5 \%$ residual milk. Thus, occasional incomplete milking could have no or small effects on milk yield at the following milking, provided that the amount of milk left remains below the threshold of $30 \%$ of milk removal and is partially stored in the cistern.

Short-term carry-over effects on milk yield were observed on subsequent milkings, but the effects were limited to M2 and M3 milkings. This duration of recovery

(b)

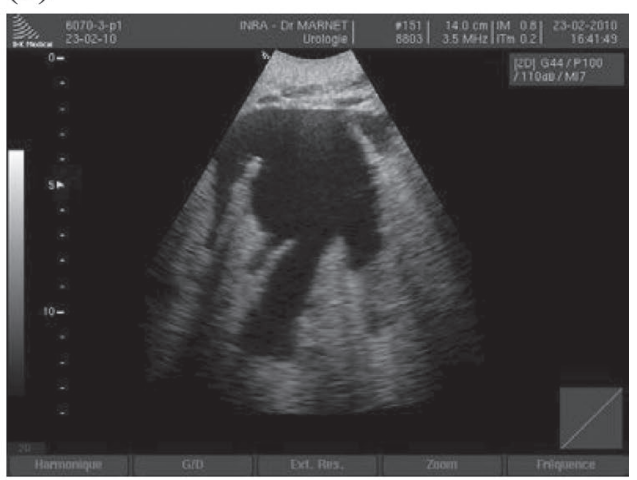

(d)

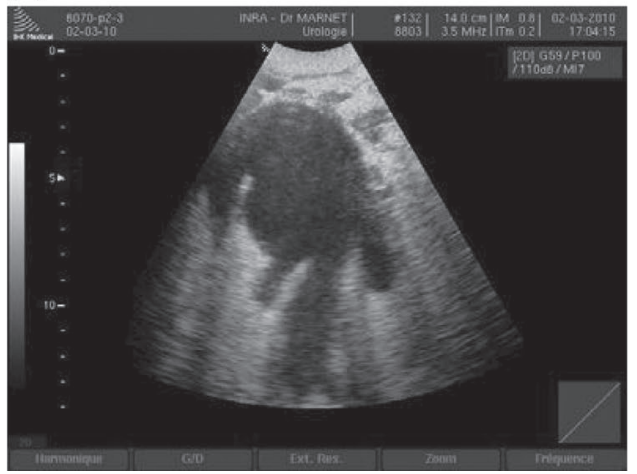

Figure 3. Cisternal scans of the right rear quarter of one representative dairy cow $9 \mathrm{~h}$ after decreasing levels of milk removal at M0 milking: $100 \%$ (a), $70 \%$ (b), 40\% (c), and 0\% (d). M0 = one morning milking. The udder cistern filled with milk appears as a dark area, and the glandular parenchyma appears as a gray-white area. 
(1)

(a)

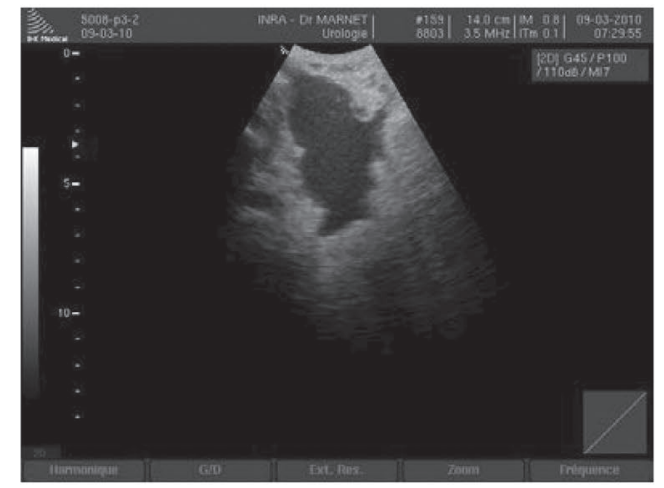

(b)

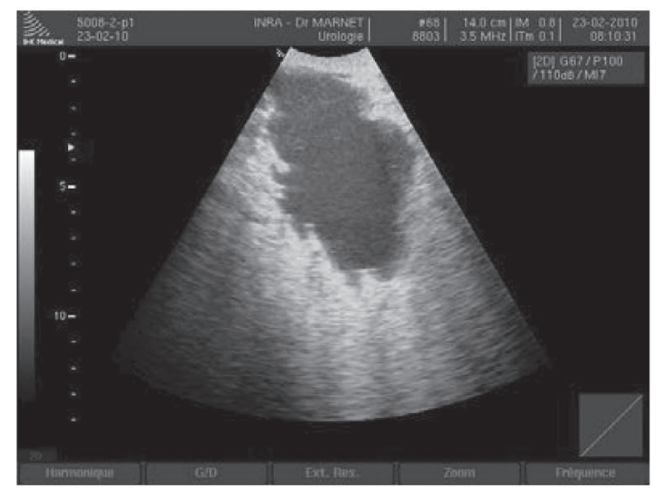

(c)
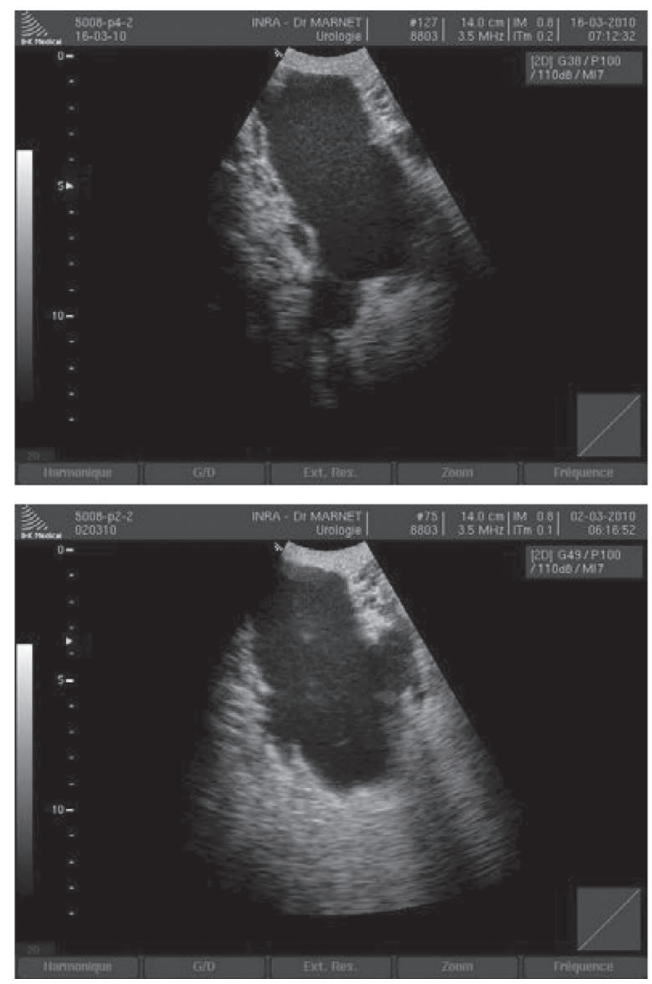

(2)
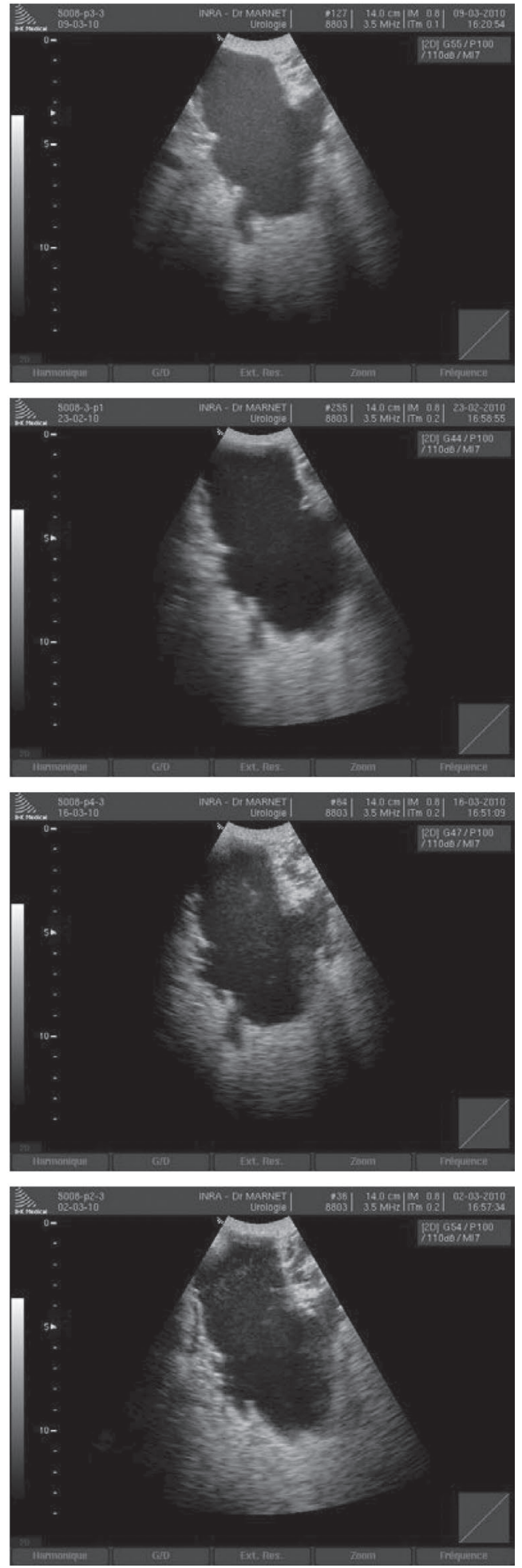

Figure 4. Cisternal scans of the right rear quarter of one representative dairy cow at levels of milk removal of 100\% (a), $70 \%$ (b), $40 \%$ (c), and $0 \%(\mathrm{~d})$ when measured $1 \mathrm{~h}(1)$ or $9 \mathrm{~h} \mathrm{(2)} \mathrm{after} \mathrm{M0} \mathrm{milking.} \mathrm{M0} \mathrm{=} \mathrm{one} \mathrm{morning} \mathrm{milking.} \mathrm{The} \mathrm{udder} \mathrm{cistern} \mathrm{filled} \mathrm{with} \mathrm{milk} \mathrm{appears} \mathrm{as} \mathrm{a} \mathrm{dark}$ area, and the glandular parenchyma appears as a gray-white area. 


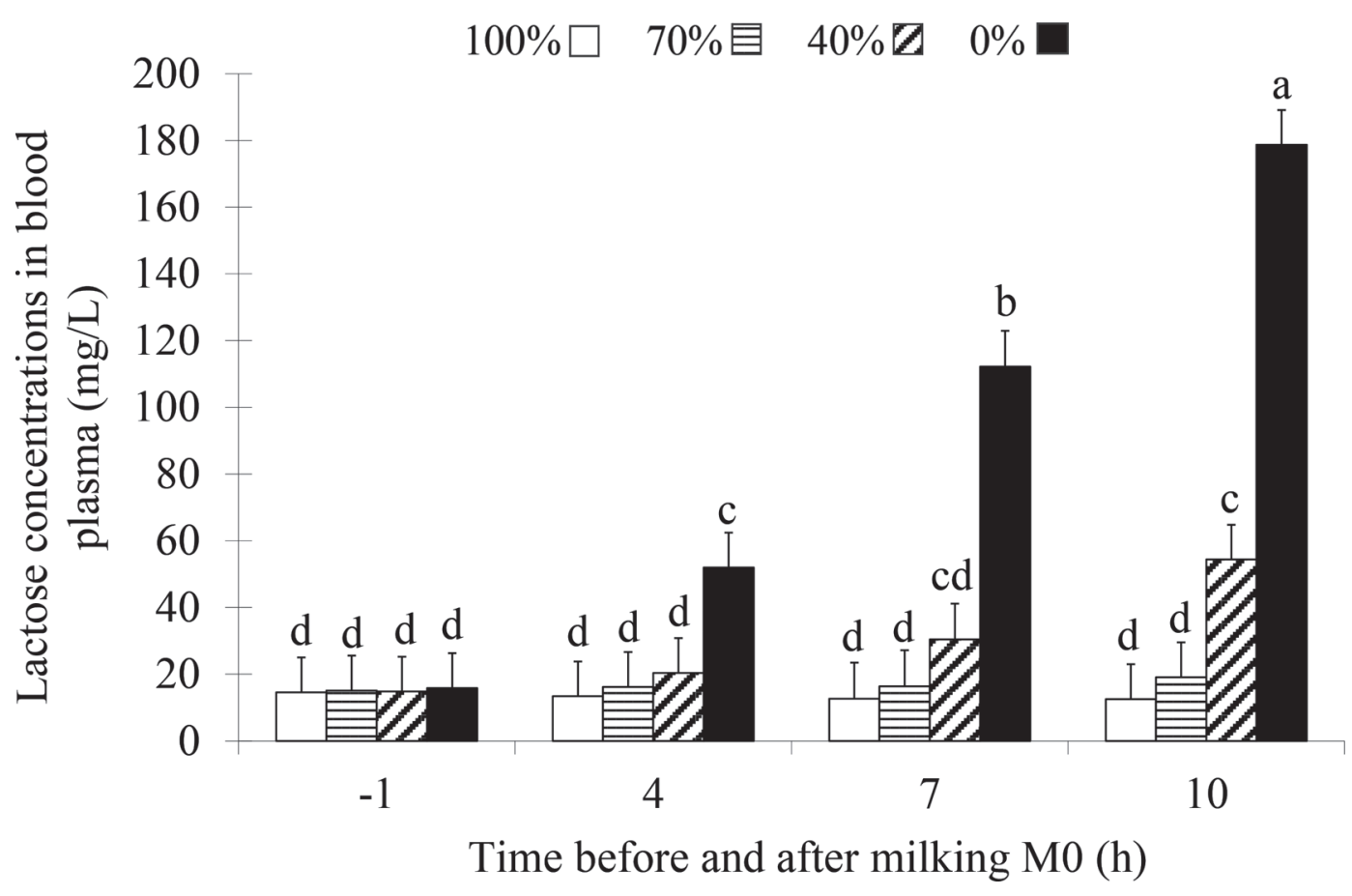

Figure 5. Concentration of lactose in blood plasma $1 \mathrm{~h}$ before and 4, 7, and $10 \mathrm{~h}$ after decreasing levels of milk removal at M0 milkings in dairy cows $(100,70,40$, and $0 \%)$. M0 = one morning milking. Values with different letters (a-d) differ at $P<0.05$. Vertical bars represent SEM.

agrees with those previously reported when considering the more constraining treatment in this trial (i.e., the omission of one daily milking; Labussière and Coindet, 1968; Radcliffe et al., 1973; Charton et al., 2016). In experiments with no change in the times of subsequent milking, milk yield returned to initial levels in the next 2 d. Stelwagen et al. (2008) reported that this recovery period could be shortened to $24 \mathrm{~h}$ by increasing the milking frequency (a 6-h interval) for subsequent milkings. Milking frequency is not the only source of variation in the duration of the recovery period; it also depends on animal characteristics. Indeed, Charton et al. (2016) reported that cows in early lactation more quickly recovered the milk they lost during a 24-h extended milking interval. In addition, primiparous cows had better milk recovery than did multiparous cows.
Short-term carry-over effects noticed at M2 and M3 were not observed for the $70 \%$ treatment group, likely because milk left at M0 was probably in part left in the cistern. Moreover, carry-over effects observed for the 40 and $0 \%$ treatments were similar, suggesting they might not depend on the degree of incomplete milking. However, when Dodd and Clough (1962) repeated treatments of 90,75 , and $60 \%$ milk removal over $48 \mathrm{~h}$, the carry-over effects observed for all treatments were magnified when increased amounts of milk were left in the udder. Additionally, these authors reported a rate and extent of recovery that were inversely related to the length of the period of incomplete milking when $75 \%$ of the expected milk yield was removed at milking on d 4,8 , or 20 . Thus, in addition to the degree of incomplete milking, the number of repetitions of incomplete

Table 3. Milk Na and $\mathrm{K}$ concentrations at M1 milkings in response to decreasing levels of milk removal at M0 milkings in dairy cows ${ }^{1}$

\begin{tabular}{|c|c|c|c|c|c|c|}
\hline Item & \multicolumn{4}{|c|}{ Level of milk removal (\%) } & $\begin{array}{l}\text { Pooled } \\
\text { SEM }\end{array}$ & $\begin{array}{c}P \text {-value } \\
\text { milk removal effect }\end{array}$ \\
\hline$\overline{\mathrm{K}}(\mathrm{mmol} / \mathrm{L})$ & $44.7^{\mathrm{a}}$ & $45.1^{\mathrm{a}}$ & $44.4^{\mathrm{a}}$ & $42.5^{\mathrm{b}}$ & 0.56 & 0.0001 \\
\hline $\mathrm{Na} / \mathrm{K}$ ratio & $0.36^{\mathrm{c}}$ & $0.37^{\mathrm{cb}}$ & $0.43^{\mathrm{b}}$ & $0.53^{\mathrm{a}}$ & 0.027 & $<0.0001$ \\
\hline
\end{tabular}

${ }^{a-c}$ Least squares means within a row with different superscripts differ at $P<0.05$.

${ }^{1} \mathrm{M} 0$ and $\mathrm{M} 1$ = one morning milking and the subsequent milking. 
milking could be of importance in the generation of different carry-over effects in milk recovery responses. Performing 40 and $0 \%$ milk removal only once, with no repetition, could be insufficient to generate different carry-over effects between these 2 treatments on milk yield.

Stelwagen et al. (2008) also studied carry-over effects without any repetition of treatments. They studied the effects of increasing both the quantity of milk stored and the duration of storage by using single 6-, 12-, 18-, 24-, and 30-h milking intervals. In contrast to our results, they observed different carry-over effects between treatments: the hourly rate of milk secretion in the subsequent $24 \mathrm{~h}$ was significantly decreased among cows previously exposed to the longest milking intervals. This difference suggests that the magnitude of carry-over effects induced by a large quantity of milk stored into the udder could depend on the duration of the milking interval to a greater extent than it does on the volume of milk stored.

\section{Milk Composition at M1 and Subsequent Milkings}

Yields of milk constituents varied throughout the experiment concomitantly with milk yield but not always proportionally, inducing changes in milk composition that differed between components. According to Wheelock et al. (1966), differences between milk components in response to incomplete milking are similar to those observed with increasing milking intervals. These changes reflect mammary modifications that have been described in the literature, such as downregulation of the synthesis of milk components (see reviews of Davis et al., 1999, and Stelwagen, 2001), transient inflammation of the udder (Stelwagen and Lacy-Hulbert, 1996; Lakic et al., 2011), and a loss of permeability of mammary epithelium (Stelwagen et al., 1997).

During the M0-M1 milking interval, milk fat yield decreased less than milk yield, inducing a marked increase in milk fat concentration $(+1$ unit for the $0 \%$ compared with the $100 \%$ treatment). According to Guinard-Flament et al. (2011b), milk fat synthesis is simultaneously but relatively less affected than the aqueous phase components in the course of milk accumulation in the udder. This lower downregulation of milk fat synthesis could result from a metabolic adaptation in the udder, driven either to limit the decrease in milk energy value for newborns (Davis et al., 1999) or to buffer the excess energy in the organism (GuinardFlament et al., 2011b).

In the present experiment, milk protein concentrations did not vary between treatments at M1. This contrasts with the increase previously reported when using a 24-h milking interval (Stelwagen et al., 2008; Lakic et al., 2009; Charton et al., 2016) or incomplete milking during 4 and 8 successive milkings (Wheelock et al., 1965). A rise in milk protein concentration is usually observed and is due either to an increased casein concentration (Lakic et al., 2009), increased soluble protein concentration (Wheelock et al., 1966; Stelwagen et al., 2008), or both (Wheelock et al., 1965). Here, decreased milk protein concentrations were observed from M2 until M5 for treatments at both 40 and $0 \%$. This contrasts with increased concentrations of whey proteins and caseins reported by Wheelock et al. (1965) on subsequent milking after incomplete (50\%) milking. To our knowledge, only Lakic et al. (2011) reported decreased milk protein concentrations at subsequent milking after a single prolonged milking interval. These were observed only at the M4 and M5 milkings due to a reduction in casein concentration. Our results warrant further investigation to understand their implications.

According to Stelwagen and Lacy-Hulbert (1996) and Lakic et al. (2009, 2011), a 24-h milking interval triggers an inflammatory reaction associated with increases in the SCC and proportion of polymorphonuclear leukocytes. In the present study, SCS was indeed increased by +1.2 units at M1 for the $0 \%$ treatment, and it remained increased until M5 for this treatment. This increased SCS at M1 contrasts with the results of Stelwagen et al. (2008), who reported no increase in SCS during the first 24-h milking interval, but agrees with that of Stelwagen and Lacy-Hulbert (1996), Lakic et al. (2009, 2011), and Charton et al. (2016). Similar to Lakic et al. $(2009,2011), 2$ to 3 d were necessary for SCS to return to initial values. No inflammatory reaction was observed for the $70 \%$ treatment group, perhaps because the quantity of milk left in the udder was small and partially stored in the cistern. For the $40 \%$ treatment group, an inflammatory reaction was observed only after M1 milkings and lasted until M5.

\section{Mammary Adaptation to Decreasing Degrees of Milk Removal}

As far as we know, no previous studies have associated the measurements of udder morphology indicators used in our trial (cisternal area assessed by ultrasonography and the total distance between teats) with indicators of TJ integrity (plasma lactose concentration and milk $\mathrm{Na} / \mathrm{K}$ ratio). In accordance with the literature, these 4 parameters were assumed to reflect the amount of milk stored in the cisternal compartment of the udder, the distension of the udder and mammary TJ integrity. According to Bruckmaier et al. (1994) and Ayadi et al. (2003), the cisternal area calculated from ultrasonography provides a good estimate of the quantity of milk stored in the cistern. These authors reported a positive 
correlation between cisternal area and cisternal milk volume that was highest in the 8- to 12 -h period after milking ( $\mathrm{r}=0.88,0.80$, and 0.84 with $8-, 10-$, and $12-\mathrm{h}$ milking intervals, respectively) and lowest at longer milking intervals $(\mathrm{r}=0.63,0.51$, and 0.46 with $16-, 20-$, and 24-h milking intervals, respectively). The measurement of the total distance between teats to characterize adaptation to extended milking intervals in dairy cows is fairly recent (Charton, 2017), and some evidence indicates that this criterion can reliably provide information about udder distension (Miller et al., 1995). Describing the variability of milk yield losses among cows in response to a 24 -h milking interval, Charton (2017) showed that cows with a smaller increase in the total distance between teats during the extended interval, indicating less udder distension, exhibited greater milk yield losses. With regard to mammary epithelium permeability, Stelwagen et al. (1994, 1997) described the occurrence of molecule transfer between blood and milk during the extended milking interval, leading to an increase in lactose concentration in the blood plasma and to changes in the ionic composition of milk, with an increase in $\mathrm{Na}$ concentration and a decrease in $\mathrm{K}$ concentration. This transfer occurs from $18 \mathrm{~h}$ of milk accumulation in bovine udders (Stelwagen, 2001; Guinard-Flament et al., 2011a). This lactose efflux from the mammary gland would be related to degree of milk udder filling independent of the duration of milking interval as suggested by Stelwagen and Singh (2014) who showed that the time at which lactose efflux into blood plasma was delayed or hastened when cisternal compartment was either drained or filled by milk-like fluid infusion. Although this efflux of lactose might partly result from pressure differential between milk and interstitial fluid, the rapid increase in plasma lactose concentrations is associated with opening of mammary TJ (Stelwagen et al., 1997; Davis et al., 1999).

In the present experiment, milk not removed from the udder at M0 remained at least partially in the cistern, as shown by the larger cisternal areas observed $1 \mathrm{~h}$ after M0. For the 40 and $0 \%$ treatments, cisternal areas were not different $1 \mathrm{~h}$ after M0, suggesting that similar amounts of milk were stored in the cistern. This assumption might not be completely true. For the 0\% treatment, a 15.5-h milk accumulation occurred in the udder at the M0 milking. According to Ayadi et al. (2003), the correlation between cisternal area and cisternal milk volume is lower after $16 \mathrm{~h}$ of milk accumulation due to difficulties in visualizing the full cisternal compartment. Just before M1 milkings, the cisternal area for the $0 \%$ treatment was not increased significantly, showing only a $9 \%$ increase. This suggests that either the additional milk filling up the cistern did not generate marked changes in cisternal area or the cistern was almost full of milk after the M0 milking.

Between the M0 and M1 milkings, the increases in total teat distances and in cisternal areas were smaller when the milk secretion rate was more depressed. Thus, our results show a clear reduction in milk secretion when cisternal storage and udder distension were not increased further or were increased only very slightly and became limiting factors. This agrees with Stelwagen et al. (1996) and Davis et al. (1998), who reported that milk drainage from alveoli to the cistern and the cistern pool size are important in determining the loss of milk production during a long milking interval. A higher reduction in milk yield was also reported in cows that had a lower proportion of produced milk stored within the cistern (Knight et al., 1994; Stelwagen and Knight, 1997). Accordingly, this was associated with enhanced leakage of lactose from milk to blood, probably due to alveolar distension (Davis et al., 1999; Stelwagen and Singh, 2014). A decline in milk secretion in response to either an extended milking interval or increasing amounts of milk left in the udder involves an impairment of mammary function. Our study of the loss of mammary epithelium permeability provides information about the time at which this permeability begins to increase. Plasma lactose concentrations began to increase significantly $4 \mathrm{~h}$ after $\mathrm{M} 0$ for the $0 \%$ treatment (i.e., after $18.5 \mathrm{~h}$ of milk accumulation in the udder), consistent with previous findings (Stelwagen, 2001; Guinard-Flament et al., 2011b). For the $40 \%$ treatment, plasma lactose concentrations increased significantly at a later time point (10 h after M0) probably as a result of a lower degree of udder filling. Assuming that the beginning of the loss of TJ integrity is associated with the beginning of decreased milk synthesis and secretion, the downregulation of milk secretion likely occurred earlier following the $0 \%$ treatment than following the $40 \%$ treatment. This suggests that milk yield could be reduced to a greater extent if milk secretion begins to decline earlier.

If true between cows, this would at least partially explain the large individual variability in milk yield losses observed in cows switched to a single 24-h milking interval (Charton et al., 2016; Charton, 2017). In the past, Guinard-Flament et al. (2011a) tested the hypothesis that high levels of plasma lactose concentrations after $23 \mathrm{~h}$ of milk accumulation indicate greater losses in milk yield and can help identify cows that are sensitive to milk accumulation. However, they reported a very low correlation between plasma lactose concentrations and milk yield losses. In contrast, after cluster analysis, Charton (2017) observed that cows having the largest increases in plasma lactose concentrations (above $100 \mathrm{mg} / \mathrm{mL}$ ) were more numerous in 
clusters showing smaller decreases in milk yield losses (\%). In the present study, results suggest that dairy cows exhibiting the earliest increases in plasma lactose concentrations would also have the highest milk yield loss (\%). The results for the $0 \%$ treatment support this hypothesis. Among the 16 cows included in the study, milk yield losses in response to a 24-h milking interval were greater than $30 \%$ for 9 cows, between 20 and $30 \%$ for 4 cows, and below $20 \%$ for 3 cows. Four hours after M0, most of the 9 cows with a greater than $30 \%$ loss showed increases in plasma lactose greater than +30 $\mathrm{mg} / \mathrm{L}(\mathrm{n}=7)$. In contrast, all cows showing losses of less than $30 \%$ showed increases in plasma lactose of less than $+30 \mathrm{mg} / \mathrm{L}$. An increase of $30 \mathrm{mg} / \mathrm{L}$ is relatively small compared with the plasma lactose concentrations observed just before M1 for some cows (500 $\mathrm{mg} / \mathrm{L}$ ), but this could be sufficient to denote a change in mammary barrier integrity. Additionally, cows with milk yield losses greater than $30 \%$ had the smallest increases in plasma lactose concentrations during the period between 7 and $10 \mathrm{~h}$ after M0: $+15 \%( \pm 19.7)$ versus $+72 \%( \pm 27.5)$ and $+146 \%( \pm 58.8)$ for cows with $30-20 \%$ and $<20 \%$ milk yield losses, respectively. This could indicate that, due to a strong inhibitory effect on milk secretion for these sensitive cows, the leakage of lactose from milk to blood remained moderate, with no further sharp increase. Thus, in response to a lengthened milking interval, the dairy cows most sensitive to milk accumulation (i.e., having the highest losses in milk yield), would have the earliest increases in plasma lactose concentrations, with limited increases at the end of the milk accumulation interval. Although this result has to be confirmed with a larger sample size, because of the limited number of cows included in the present trial $(\mathrm{n}=16)$, it suggests that this time could be a relevant indicator of the ability of dairy cows to tolerate extended milking intervals.

\section{CONCLUSIONS}

The present study suggests that the hourly rate of milk secretion due to extended milking intervals depends on the quantity of milk stored in the udder of dairy cows. However, if this quantity is of importance in regulating milk secretion, its effect is less than the combined effects of both the quantity of the milk stored and the duration of the milking interval with regard to carry-over effects. This study also confirms the relevance of measuring blood plasma lactose concentrations to describe the loss of integrity of the alveolar blood-milk barrier. Blood plasma lactose concentrations exhibited a rapid increase in relation to higher amounts of milk stored in the udder. This was observed when cisternal capacity, based on cisternal area, and the distension of the udder, based on the total distance between teats, were maximal. The rate of milk secretion on subsequent milkings was reduced only when lactose concentrations were increased in blood plasma, suggesting that alveolar blood-milk barrier permeability is associated with an alteration of mammary metabolic and secretory activity lasting several days. In addition, lactose in the blood could reflect the ability of cows to tolerate extended milking intervals. The dairy cows most sensitive to milk accumulation (i.e., cows with the highest \% losses in milk yield) showed the earliest increase in blood plasma lactose concentrations, with limited increases in the course of milk accumulation in the udder. These results have to be confirmed by additional investigations with more individuals to determine their interest for identifying and predicting cows more adapted to extended milking intervals.

\section{ACKNOWLEDGMENTS}

The authors thank the Association GALA (Janzé, France) for providing financial support to perform the experiment. We thank M. Fargetton and all the staff at the INRA experimental farm of Méjusseaume for their help with animal care and handling. We also thank G. Théaud for help in data collection, and the laboratory technicians (N. Huchet, T. Le Mouël, and P. Debournoux; INRA-UMR Pegase, France) for their help on analyzing the samples.

\section{REFERENCES}

Armstrong, D. 1997. Milking frequency. Pages 79-84 in Proc. Western Dairy Management Conference, Las Vegas, NV. Accessed Jan. 20, 2005. http://www.wdmc.org/1997/MilkingFrequency.pdf.

Ayadi, M., G. Caja, X. Such, and C. H. Knight. 2003. Use of ultrasonography to estimate cistern size and milk storage at different milking intervals in the udder of dairy cows. J. Dairy Res. 70:1-7. https://doi.org/10.1017/S0022029902005873.

Brocard, V., G. Trou, J. Flament, F. Gervais, N. Muller, and K. Quéméneur. 2015. Milking practices of Breton dairy farmers with reduced milking intervals. Page 209 in Proc. 66th Annual Meeting of European Federation of Animal Science, Warsaw, Poland. Wageningen Academic Publishers, Wageningen, the Netherlands.

Bruckmaier, R. M., E. Rothenanger, and J. W. Blum. 1994. Measurement of mammary gland cistern size and determination of the citernal milk fraction in dairy cows. Milchwissenschaft 49:543-546.

Charton, C. 2017. Caractérisation de l'adaptation de la glande mammaire des vaches laitières à l'allongement de l'intervalle entre traites. PhD Thesis. Spécialité Biologie et Agronomie, Agrocampus Ouest, Rennes, France.

Charton, C., H. Larroque, C. Robert-Granié, D. Pomiès, H. Leclerc, N. C. Friggens, and J. Guinard-Flament. 2016. Individual responses of dairy cows to a 24-hour milking interval. J. Dairy Sci. 99:31033112. https://doi.org/10.3168/jds.2015-9782.

Davis, S. R., V. C. Farr, P. J. Copeman, V. R. Carruthers, C. H Knight, and K. Stelwagen. 1998. Partitioning of milk accumulation between cisternal and alveolar compartments of the bovine udder: Relationship to production loss during once daily milking. J. Dairy Res. 65:1-8. 
Davis, S. R., V. C. Farr, and K. Stelwagen. 1999. Regulation of yield loss and milk composition during once-daily milking: A review. Livest. Prod. Sci. 59:77-94. https://doi.org/10.1016/S0301 -6226(98)00204-8.

Dodd, F. H., and P. A. Clough. 1962. The effect of various degrees of incomplete milking on milk and butterfat secretion. Pages 89-97 in Proc. 16th International Dairy Congress, Copenhagen, Denmark. International Dairy Federation, Schaerbeek, Belgium.

Dutreuil, M., J. Guinard-Flament, M. Boutinaud, and C. Hurtaud 2016. Effect of duration of milk accumulation in the udder on milk composition, especially on milk fat globule. J. Dairy Sci. 99:39343944. https://doi.org/10.3168/jds.2015-10002.

Elliott, G. M., F. H. Dodd, and P. J. Brumby. 1960. Variations in the rate of milk secretion in milking intervals of 2-24 hours. J. Dairy Res. 27:293-308. https://doi.org/10.1017/S0022029900010360.

Guinard-Flament, J., Y. Gallard, and H. Larroque. 2011a. Lactose in blood plasma and the ability of dairy cows to tolerate oncedaily milking in terms of milk loss and milk recovery. J. Dairy Sci. 94:3446-3454. https://doi.org/10.3168/jds.2010-4081.

Guinard-Flament, J., S. Lemosquet, E. Delamaire, G. Le Bris, P. Lamberton, and C. Hurtaud. 2011b. Alteration of the nutrient uptake by the udder over an extended milking interval in dairy cows. J. Dairy Sci. 94:5458-5468. https://doi.org/10.3168/jds.2011-4268.

Ichikawa, T., and T. Fujishima. 1982. Effects of 6.5 and 17.5 hour milking intervals on the yield and udder health in dairy cows. Jpn. J. Zootech. Sci. 53:355-358. https://doi.org/10.2508/chikusan.53 .355 .

INRA. 2007. Nutrition of Cattle, Sheep and Goats: Animal Needs-Values of Feeds. Quae Ed., Versailles, France.

Knight, C. H., D. Hirst, and R. J. Dewhurst. 1994. Milk accumulation and distribution in the bovine udder during the interval between milkings. J. Dairy Res. 61:167-177. https://doi.org/10 $.1017 /$ S0022029900028181

Labussière, J., and J. Coindet. 1968. Effets de la suppression de la traite du dimanche soir chez les bovins de race française Frisonne Pie noire. Ann. Zootech. 17:231-244. https://hal.archives-ouvertes .fr/hal-00886932.

Lakic, B., K. S. Sjaunja, L. Norell, J. Dernfalk, and K. Ostensson. 2011. The effect of a single prolonged milking interval on inflammatory parameters, milk composition and yield in dairy cows. Vet. Immunol. Immunopathol. 140:110-118. https://doi.org/10.1016/j .vetimm.2010.11.022.

Lakic, B., E. Wredle, K. Svennersten-Sjaunja, and K. Ostensson. 2009. Is there a special mechanism behind the changes in somatic cell and polymorphonuclear leukocyte counts, and composition of milk after a single prolonged milking interval in cows? Acta Vet. Scand. 51. https://doi.org/10.1186/1751-0147-51-4.

Miller, R. H., L. A. Fulton, B. Erez, W. F. Williams, and R. E. Pearson. 1995. Variation in distances among teats of Holstein cows: Implications for automated milking. J. Dairy Sci. 78:1456-1462. https://doi.org/10.3168/jds.S0022-0302(95)76767-4.

Murthy, G. K., and U. Rhea. 1967. Determination of major cations in milk by atomic absorption spectrophotometry. J. Dairy Sci. 50:313-317. https://doi.org/10.3168/jds.S0022-0302(67)87416-2.

Negrao, J. A., and P. G. Marnet. 2006. Milk yield, residual milk, oxytocin and cortisol release during machine milking in Gir, Gir x Holstein and Holstein cows. Reprod. Nutr. Dev. 46:77-85. https:// doi.org/10.1051/rnd:2005068.
Radcliffe, J. C., L. F. Bailey, and M. L. Horne. 1973. Periodic omission of dairy cow milkings: I. Effect on milk yield and composition and on udder health. J. Dairy Res. 40:247-254. https://doi.org/10 $.1017 /$ S0022029900014576.

Rémond, B., D. Pomiès, C. Julien, and J. Guinard-Flament. 2009. Performance of dairy cows milked twice daily at contrasting intervals. Animal 3:1463-1471. https://doi.org/10.1017/S1751731109990371.

Sabuncuoglu, N., and O. Coban. 2007. Relationship between udder and teat conformation and milk yield performance in dairy cows pre and post-milking. Can. J. Anim. Sci. 87:285-289. https://doi .org/10.4141/A06-074.

Schmidt, G. H., R. S. Guthrie, and R. W. Guest. 1964. Effect of incomplete milking on the incidence of udder irritation and subsequent milk yield of dairy cows. J. Dairy Sci. 47:152-155. https:// doi.org/10.3168/jds.S0022-0302(64)88608-2.

Stelwagen, K. 2001. Effect of milking frequency on mammary functioning and shape of the lactation curve. J. Dairy Sci. 84(E-Suppl.):204-211. https://doi.org/10.3168/jds.S0022-0302(01)70219-6.

Stelwagen, K., S. R. Davis, V. C. Farr, C. G. Prosser, and R. A. Sherlock. 1994. Mammary epithelial cell tight junction integrity and mammary blood flow during an extended milking interval in goats. J. Dairy Sci. 77:426-432. https://doi.org/10.3168/jds.S0022 -0302(94)76969-1.

Stelwagen, K., V. C. Farr, H. A. McFadden, C. G. Prosser, and S. R. Davis. 1997. Time course of milk accumulation-induced opening of mammary tight junctions, and blood clearance of milk components. Am. J. Physiol. 273:R379-R386.

Stelwagen, K., V. C. Farr, G. D. Nicholas, S. R. Davis, and C. G. Prosser. 2008. Effect of milking interval on milk yield and quality and rate of recovery during subsequent frequent milking. Livest. Sci. 114:176-180. https://doi.org/10.1016/j.livsci.2007.04.021.

Stelwagen, K., and C. H. Knight. 1997. Effect of unilateral once or twice daily milking of cows on milk yield and udder characteristics in early and late lactation. J. Dairy Res. 64:487-494.

Stelwagen, K., C. H. Knight, V. C. Farr, S. R. Davis, C. G. Prosser, and T. B. McFadden. 1996. Continuous versus single drainage of milk from the bovine mammary gland during a 24 hour period. Exp. Physiol. 81:141-149. https://doi.org/10.1113/expphysiol .1996.sp003915.

Stelwagen, K., and S. J. Lacy-Hulbert. 1996. Effect of milking frequency on milk somatic cell count characteristics and mammary secretory cell damage in cows. Am. J. Vet. Res. 57:902-905.

Stelwagen, K., and K. Singh. 2014. The role of tight junctions in mammary gland function. J. Mammary Gland Biol. Neoplasia 19:131138. https://doi.org/10.1007/s10911-013-9309-1.

Swett, W. W., P. C. Underwood, C. A. Matthews, and R. R. Graves. 1942. Arrangement of the tissues by which the cow's udder is suspended. J. Agric. Res. 65:19-43. https://naldc.nal.usda.gov/ naldc/download.xhtml?id=IND43969716\&content $=$ PDF .

Wheelock, J. V., J. A. F. Rook, and F. H. Dodd. 1965. The effect of incomplete milking or of an extended milking interval on the yield and composition of cow's milk. J. Dairy Res. 52:237-248. https:// doi.org/10.1017/S0022029900018604.

Wheelock, J. V., J. A. F. Rook, F. H. Dodd, and T. K. Griffin. 1966. The effect of varying the interval between milkings on milk secretion. J. Dairy Res. 33:161-176. https://doi.org/10.1017/ S0022029900011833. 